\title{
A patient with $D A X 1$ mutation presenting with elevated testosterone in early infancy
}

\author{
Juan $\mathrm{Ge}^{1} \cdot$ Tang $\mathrm{Li}^{1,2}$ \\ Received: 25 December 2018 / Accepted: 4 February 2019 / Published online: 20 March 2019 \\ (c) The Author(s) 2019
}

Dosage-sensitive sex reversal-adrenal hypoplasia congenita critical region on the $\mathrm{X}$ chromosome 1 (DAX1) deficiency is a rare disorder presents $\mathrm{X}$-Linked adrenal hypoplasia congenital, impaired sexual development and infertility. Mutational gene of DAX1 was identified as NROB1 [1] which expresses in adrenal gland and hypothalamic-pituitary-gonad axis, restrains progenitor stem cells from differentiating into steroidogenic cells prematurely. Therefore, DAX1 deficiency usually manifests primary adrenal insufficiency and hypogonadotropic hypogonadism. However, we observed a patient whose testosterone elevated in early infancy.

With uneventful pregnancy and birth history, the patient got intractable jaundice. There is a maternal uncle died young suddenly in the family history. Biochemical findings showed persistent hyponatremia (120.9-133 mmol/L), hyperkalemia $(6.4-9.1 \mathrm{mmol} / \mathrm{L})$ and hyperbilirubinemia. His blood sugar, 17-hydroxyprogesterone, creatine kinase, very-long-chain fatty acid and gas chromatography mass spectrometry were normal. First hormone analysis showed adrenal insufficiency and elevated testosterone (Table 1). Ultrasound showed adrenal region got hypoechoic nodule that recognized as small adrenal gland. Genetic test found a pathogenic mutation of c.1169-1G $>\mathrm{T}$ in NROBI from his mother.

After treatment with hydrocortisone, fludrocortisone and sodium salt replacement, his electrolyte gradually adjusted to normal in a month, and testosterone reduced to normal in 4 months (Table 1). Growth and development were under our observation as well. Delayed bone age and smaller testes were consistent with his disease.

Primary adrenal insufficiency combined with high testosterone tends to be diagnosed as congenital adrenal hyperplasia. From this case, we summarize DAX1 deficiency's differential points as normal 17-hydroxyprogesterone, delayed bone age and confirmation of mutation in NROB1.Adrenal ultrasound also has certain value for distinguishing it from congenital adrenal hyperplasia.

Although most patients manifest sexual development failure, many reports broaden its clinical spectrum. Spontaneous or even precocious puberty happen but basically suspend in Tanner stage 2 to 3 [2,3]. In this case, we observed elevated sexual hormones initially. Minipuberty was found in one case as well caused by a mutation of c.518del23 [4]. Another case was found with elevated testosterone since 9 months old with Trp291Arg in NROBI [5]. As testicular histological examination has been reported as intact in affected neonate [6], and testosterone can also be stimulated by human chorionic gonadotropin during early time [2], testicular structure and function can be normal but progressively impaired as increasing age. Excluding ectopic secretory tissue, testes can be reasonable origin for testosterone in early life.
Tang Li

drlitang@hotmail.com

Medical Department, Qingdao University, Qingdao, China

2 Department of Pediatric Endocrinology and Genetic Metabolic Diseases, Qingdao Women and Children's Hospital, Qingdao, China 


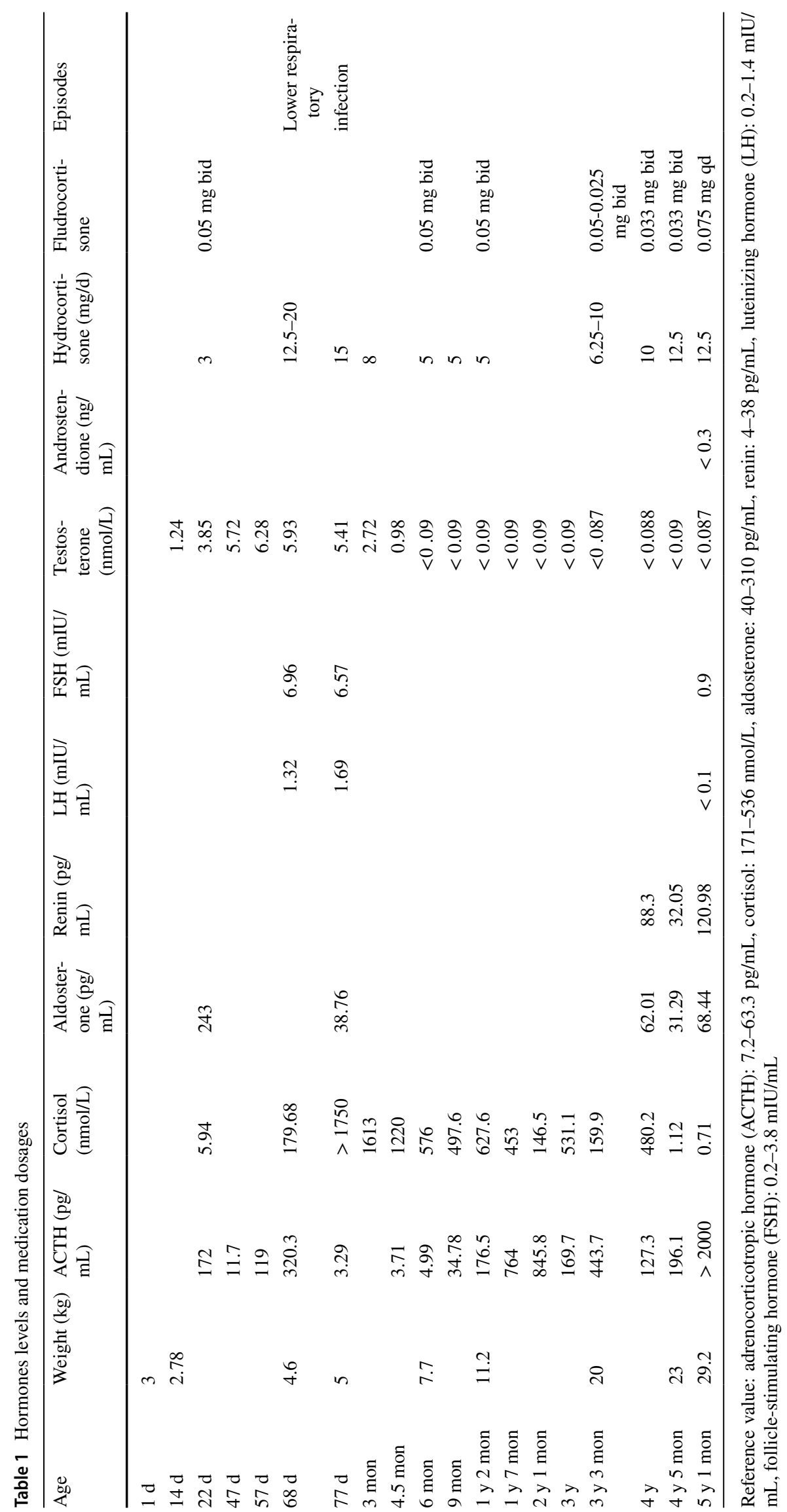


Overall, although patients with DAX1 deficiency commonly present hypogonadism, individual case may have temporal elevated testosterone which confuses its diagnosis.

Author contributions JG: collected and analyzed data, and drafted the manuscript. TL: designed the study, organized the clinical follow-up study and reviewed the manuscript.

\section{Funding None.}

\section{Compliance with ethical standards}

Ethical approval This study was approved by the Ethical Committee of Qingdao Women and Children's Hospital.

Conflict of interest No financial or nonfinancial benefits have been received or will be received from any party related directly or indirectly to the subject of this article.

Open Access This article is distributed under the terms of the Creative Commons Attribution 4.0 International License (http://creativeco mmons.org/licenses/by/4.0/), which permits unrestricted use, distribution, and reproduction in any medium, provided you give appropriate credit to the original author(s) and the source, provide a link to the Creative Commons license, and indicate if changes were made.

\section{References}

1. Muscatelli F, Strom TM, Walker AP, Zanaria E, Récan D, Meindl A, et al. Mutations in the DAX-1 gene give rise to both X-linked adrenal hypoplasia congenita and hypogonadotropic hypogonadism. Nature. 1994;372:672-6.

2. Galeotti C, Lahlou Z, Goullon D, Sarda-Thibault H, Cahen-Varsaux J, Bignon-Topalovic J, et al. Longitudinal evaluation of the hypothalamic-pituitary-testicular function in 8 boys with adrenal hypoplasia congenita (AHC) due to NR0B1 mutations. PLoS One. 2012;7:e39828.

3. Landau Z, Hanukoglu A, Sack J, Goldstein N, Weintrob N, Eliakim A, et al. Clinical and genetic heterogeneity of congenital adrenal hypoplasia due to NROB1 gene mutations. Clin Endocrinol (Oxf). 2010;724:448-54.

4. Kaiserman KB, Nakamoto JM, Geffner ME, McCabe ER. Minipuberty of infancy and adolescent pubertal function in adrenal hypoplasia congenita. J Pediatr. 1998;133:300-2.

5. Yeste D, González-Niño C, Pérez de Nanclares G, Pérez-Nanclares G, Audi L, Castaño L, et al. ACTH-dependent precocious pseudopuberty in an infant with DAX1 gene mutation. Eur J Pediatr. 2009;168:65-9.

6. Brown P, Scobie GA, Townsend J, Bayne RA, Seckl JR, Saunders PT, et al. Identification of a novel missense mutation that is as damaging to DAX-1 repressor function as a nonsense mutation. $\mathbf{J}$ Clin Endocrinol Metab. 2003;88:1341-9.

Publisher's Note Springer Nature remains neutral with regard to jurisdictional claims in published maps and institutional affiliations. 